delighted in physics. But there is something a bit muted in the later letters, especially the more intimate ones. Much of Feynman's passionate engagement flowed through his physics. This comes across remarkably well in the letters Michelle Feynman has chosen - in his enthusiastic responses to friends, colleagues, students and physics hobbyists. $\mathrm{He}$ advised, cajoled and encouraged: Try this, think about that, have courage in your ideas, think for yourself.

Occasionally, Feynman's passion for physics - for control over a world he imagined he could create entirely by himself - slid into a disdain toward everything non-scientific. In one exchange, he pronounced dismissively on poetry and in particular on poets' insufficient appreciation of physicists' vision of the world: "My lament was that a kind of intense beauty that I see given to me by science, is seen by so few others; by few poets and therefore, by even fewer more ordinary people."

Although Feynman's physics at times resem- bles the physics of the young Einstein, his presence in the world is very different. Einstein never lost his fascination for philosophy, for Kant or for his near-contemporary, Poincaré. Feynman found philosophers nothing but a burden, a vulture-like presence that swooped in when strong ideas were dying. And while Einstein came to believe that physical reality lay deep in mathematical physics, Feynman never gave up hoping for a physics driven, at bottom, by an almost tactile intuition.

Much of Einstein's life found him cast and self-cast as an oracle. Feynman preferred the persona of a fast-draw street-smart kid. Yet beyond these striking differences, both Einstein and Feynman found ways to hold their own, fiercely maintaining their positions as individuals in a time when physics and fame, as never before, pressed them to assume their place in teams and groups.

Peter Galison is in the Department of Physics, Harvard University, Science Centre 235, 1 Oxford Street, Cambridge, Massachusetts 02138, USA.

\title{
Darwin's first love
}

\section{Charles Darwin, Geologist \\ by Sandra Herbert \\ Cornell University Press: 2005. 512 pp. £21.95, \$39.95}

\section{Martin Rudwick}

In 1836, Charles Darwin returned to England after his five-year voyage on HMS Beagle. He soon became a closet evolutionist, working on his biological theory of evolution before publishing On the Origin of Species in 1859. These bare facts are not incorrect, but they are seriously incomplete. Two years after his return, reflecting on his life so far, he described himself as "I the geologist..." This was not an isolated remark - it expressed his chosen identity. Indeed, it was as a competent geologist that Darwin first came to the attention of the scientific community and made his name as a promising young 'man of science'.

His main interests gradually shifted sideways from geology into zoology and botany, but it is deeply misleading to read his career as if there was an inevitability about the move. This has been well known to Darwin specialists, but Sandra Herbert's Charles Darwin, Geologist is the first full-length treatment of his geological research, describing and analysing the work in its own right as well as in its role as a foundation for his later biological work.

Herbert's approach is not strictly biographical; some background knowledge of Darwin's life - best gleaned from Janet Browne's superbly readable two-volume Charles Darwin (Jonathan Cape, 2003) - is, in effect, taken for granted. Herbert treats Darwin's geological work as a series of specific topics, with a chronological analysis of each. Although she

IMAGE

UNAVAILABLE FOR COPYRIGHT REASONS

Blank slate: there was nothing inevitable about Darwin's evolution from geologist to biologist.

covers in outline almost his entire career, she focuses on Darwin's Beagle years, his fruitful few years in London, and the first years of his long life at Downe in Kent - in other words, on the 1830 s and early 1840 s.

As a highly respected member of the scholarly 'Darwin industry', she has an enviably thorough knowledge of the vast Darwin manuscript archive. She makes full use of the revealing details of Darwin's famous scientific notebooks and his voluminous correspondence, which greatly deepen our understanding of his published work.

Herbert rightly emphasizes that the geology to which the young Darwin contributed was already a well-established science. He had excellent informal training from Adam Sedgwick and John Henslow at the University of Cambridge, support from a substantial scientific library on board the Beagle, and inspiration from Charles Lyell's newly published
Principles of Geology. Above all, he had the stimulus of intelligent discussion at the Geological Society in London after his return.

After spreading his attention widely at first, he concentrated increasingly on one of geology's focal problems at the time: that of crustal elevation and subsidence. This underlay his interest in the effects of the great earthquake he witnessed in Chile, as well as his fieldwork in the high Andes. It led him to out-Lyell Lyell — giving an even better explanation in terms of observable processes - with his innovative theory of coral reefs, sketched in outline before he ever saw one, in which corals functioned simply as markers of crustal movement.

With sublime confidence, he anticipated that the "geology of whole world will turn out simple". His 'theory of the Earth', like Lyell's, was one that envisaged the ceaseless movement of crustal plates, not horizontally as in modern plate-tectonic theory, but vertically. However, after his return to Britain he cited the famous Parallel Roads of Glen Roy in Scotland in support of his theory, only to be upstaged by the Swiss naturalist Louis Agassiz's glacial theory, which was a far better explanation for the puzzling terraces. This was a critical challenge to 'simplicity' in the light of which Darwin eventually conceded that his own effort had been a "gigantic blunder".

Interspersed with Herbert's valuable analyses of Darwin's geological fieldwork and theorizing are chapters on other topics. In line with current trends in the historiography of other sciences, she describes in fascinating detail the practical aspects of Darwin's geology: his hammer and other instruments, his methods for collecting specimens and making notes, and so on. She also discusses the Romanticism of the travel narratives that he took as his literary models, and the contemporary debates in England about geology and Genesis. And, perhaps of greatest interest to other Darwin scholars and to biologists, she analyses with care the ways in which his geology generated the problems to which his eventual theory of the origin of new species was designed to be the solution.

I have only two reservations about this fine volume. The first is that Herbert tends to underestimate the extent to which Darwin was developing lines of research already being explored by other geologists - not only his hero Lyell but also those who were critical of Lyell's theories. Second, like Darwin himself - who was only fluent in English - she does not adequately emphasize the thoroughly international character of the geological world during the most creative period of his life. Nonetheless, this is a highly important contribution, not just to Darwin studies but also to the sadly neglected field of the history of geology itself.

Martin Rudwick is in the Department of History and Philosophy of Science, University of Cambridge, UK. His latest book, Bursting the Limits of Time, will be published by the University of Chicago Press in August. 